\title{
Ultimate Behavior of Lightweight High Strength Concrete Filled Steel Tube (LWHCFST)
}

\author{
Ayman Ismail ${ }^{1}$, Ashraf Morshed ${ }^{2}$,Sherif Yehia ${ }^{3}$ \\ ${ }^{1,2}$ (Steel and structure, Housing and Building National Research Center, Cairo, Egypt.) \\ ${ }^{3}$ (Civil Engineering Department,American University of Sharjah, United Arab Emirates)
}

\begin{abstract}
Strength and ductility of concrete members can be significantly improved with lateral confinement, usually achieved by using a steel tube casing. The concrete confinement can be utilized to make bridge lighter and have longer spans. In addition, a significant portion of the load carried concrete bridge girders is the selfweight of the girders and deck. If all or part of the girder and deck can be made using high strength lightweight concretes, there is a potential for appreciable economic savings since the self-weight could be reduced by as much as 15-20\%. The study described herein investigates the static nonlinear behavior of lightweight high strength concrete filled steel tube (LWHCFST) bridges up to failure. The current study had two specific goals. The first was to experimentally determine the static modulus of elasticity of confined high strength lightweight concrete mixture. The second was to develop a nonlinear finite element computer program to study the ultimate behavior of a filled tube (LWHCFST) example bridge. The nonlinear stress-strain behavior of confined high strength lightweight concrete is evaluated experimentally by the authors and is used to help establish a comparison between the ultimate behavior of the bridge using confined normal weight concrete and confined high strength lightweight concrete. The ultimate strength of the bridge is related to the occurrence of an equivalent failure mechanism. The study indicated that the use of (LWHCFST) is beneficial for extending bridge girder lengths.
\end{abstract}

Keywords: Concrete, Confinement, Steel, pedestrian, Ultimate, LWHC, Nonlinear analysis.

\section{INTRODUCTION}

Using CFST (concrete filled steel tubes) for the arch ribs of an arch bridge is rational since CFST is resistant to axial compressive forces. The infilled concrete delays local buckling of the steel tube and the steel tube reinforces the concrete's resistance to tension, bending moments, and shear forces [1,2].The steel tube also acts as a formwork for the concrete during construction of the bridge, thus saving a major construction cost [3]. Because of these advantages, it is possible to reduce the cost of constructing steel bridges [4,5].

The seismic properties of CFST arch bridges have been the subjects of recent research. Liu et al $[6,7,8]$ discussed the seismic characteristics of two CFST arch bridges in China and clarified the nonlinear seismic performance of the tentatively designed CFST arch bridges. Wu et al. [9] discussed the nonlinear seismic properties of a partially concrete filled steel tubular arch bridge in China and examined the effect of the filled concrete length of steel tube on nonlinear seismic responses of an arch bridge. More studies are necessary in order to fully comprehend the seismic properties of CFT arch bridges.

Mander, Priestley, and Park [10,11] and Watson, Zahn, and Park [12] have found that quantity of confining reinforcement is the most significant parameter affecting the shape of the stress-strain curve of confined concrete. The apparent compressive strength of confined concrete $\mathrm{f}_{\mathrm{cc}}$ can be calculated by Eq. (1) based on the effective lateral confining pressure $\mathrm{f}_{\mathrm{l}}$.

$$
f_{c c}^{\prime}=f_{c c}\left[2.25 \sqrt{1+\frac{7.9 f_{l}}{f_{c}^{\prime}}}-2 \frac{f_{l}}{f_{c}^{\prime}}-1.25\right]
$$

Where $f_{c}$ is the specified compressive strength of the concrete.

Yehia and Tuan [13] has performed a number of compression tests to evaluate: 1) the apparent strength increase of normal concrete under confinement, 2) stress strain curve of the normal strength concrete filled steel tube (NCFST).

A significant portion of the load carried by concrete bridge girders is the self-weight of the girders and deck. If all or part of the girder and deck can be made using lightweight concretes, there is a potential for appreciable economic savings since the self-weight could be reduced by as much as $15-20 \%$. Quite a few studies have been done on lightweight concrete. A study by Meyer and Kahn [15] concluded that the use of high strength, lightweight aggregate concrete could increase the length of simple span AASHTO I-girders by up to $4 \%$ and the length of AASHTO-PCI bulb-tee girders by up to 3 percent. Tommy and Cui [16] produced concrete 
mixtures with the 28-day cube compressive strength of the resulting lightweight aggregate concrete with density of $1590 \mathrm{~kg} / \mathrm{m} 3$ and respective strength of $34 \mathrm{MPa}$. Using which is made from expanded clay. Khaloo and Sharifian [17] investigated the effect of various concrete strength levels on behavior of steel fiber reinforced lightweight concrete (SFRLWC) under pure torsion. The variables of the testing program were: compressive strength of concrete, volume of steel fibers, and the aspect ratio of steel fibers. The concrete strengths investigated are 9,12,30 and $61 \mathrm{MPa}$. Fiber content ranges from zero to 3.0 percent by volume of matrix. A recent study carried out by ARIOZ, et al [18] showed that lightweight expanded clay aggregates can be produced from clay, waste brick powders, albeit floatation waste, and coal at various temperatures ranged from $900^{\circ} \mathrm{C}$ to $1250^{\circ} \mathrm{C}$.

\section{CONFINED Lightweight High STRENGTH CONCRETE Filled STEEL TUBE (LWHCFST) COMPRESSION TESTS}

Authors have performed a number of compression tests to evaluate the apparent strength increase of lightweight high strength concrete filled steel tube (LWHCFST) and the required stress strain for the analysis. The elastic modulus required for this analysis is obtained from a separate unconfined compression test on lightweight concrete mixture , cast inside 300-mm-long, 150-mm-diameter, and 1.65-mm-thick steel pipes (fig. 1). So, experiments have been conducted to investigate the mechanical properties of high strength lightweight concrete mixtures (compressive strength and static modulus of elasticity). Two types of coarse aggregates were used, a normal and lightweight aggregate. The lightweight aggregate used in the production of lightweight concrete mixtures is lightweight expanded clay aggregate known under the name LECA. Lightweight expanded clay aggregate is a granular ceramic material. The clay is pelletisized, dried and expanded in rotary kilns. The output LWA granules are sieved into different products. In this study LECA aggregate was separated according to its size into 2 groups of 4-8 $\mathrm{mm}$ and 8-12 mm respectively. Density of lightweight expanded clay aggregates is approximately $400 \mathrm{~kg} / \mathrm{m} 3$. The moisture content after 24 -hours submersion was about $22 \%$ by weight. Crushed stone was used as normal weight concrete. The crushed stone was $12 \mathrm{~mm}$ maximum nominal size with a $1 \%$ absorption value, and its specific gravity (SSD) was 2.73 .

The fine aggregate employed in this study was a well-graded siliceous type having a specific gravity of 2.63 and a fineness modulus of 2.45. High-range water- reducing admixture based on naphthalene sulfonate, melamine formaldehyde sulfonate, and polycarboxylate was used in the dosage of 0.5 to $0.8 \%$ of the weight of the binder. The mix design of lightweight concrete used for structural purposes is more complicated because it depends on the type of lightweight aggregate. In this study, concrete mixtures were prepared using a waterbinder ratio of 0.40 . The concrete mixtures were designated as per ACI 213. The LECA was submerged in water for 24-hours to allow most of the pores in the aggregate to become water-filled. Just prior to batching, the LECA was spread on burlap for 30-minutes to get a dry surface condition. Normal weight aggregates were replaced by LECA with size fractions of 4-8 mm and 8-12 $\mathrm{mm}$ at three different weight fractions such as $60 \%, 80 \%$ and $100 \%$ of the coarse total aggregate weight of concrete. The mixtures were varied by replacement of natural coarse aggregate by LECA up to $100 \%$ by weight. The percentage of LECA, within the whole aggregates was 60,80 and $100 \%$ by weight. The concrete mixtures were designed to weight $1900 \mathrm{~kg} / \mathrm{m} 3$. For each mix, nine $100-\mathrm{mm}$ size cubes were cast to determine the compressive strength at the age of 3, 7, and 28 days while static modulus of elasticity testing were performed at 28-days according to ASTM C496 using cylinders of $150 \mathrm{~mm}$ diameter and $300 \mathrm{~mm}$ in length. At 28 days, the same cubes used for compressive strength were also used to test the density at saturated-surface dried (SSD) condition. They were left in the mould in the laboratory at $20 \pm 2 \mathrm{oC}$ for one day and then removed from the moulds. After that, they were cured in water at $20 \pm 2 \mathrm{oC}$ for two days, and then wrapped in polythene sheet and left in the laboratory at $20 \pm 20 \mathrm{C}$ until they were tested. After $24 \mathrm{~h}$, all the test specimens were demoulded and then The samples were then removed from the molds after 24 hours and were kept in the standard cure pool at $20 \pm 2^{\circ} \mathrm{C}$. Table 1 presents properties of the selected concrete mixture.

TABLE 1 : Concrete Mixture Properties

\begin{tabular}{|c|c|c|c|}
\hline \multicolumn{3}{|c|}{ Cement $\mathrm{kg}$} & 420 \\
\hline \multicolumn{3}{|c|}{$\begin{array}{ll}\text { F.A } & \mathrm{kg} \\
\end{array}$} & 624 \\
\hline \multirow{2}{*}{$\begin{array}{l}\text { LECA } \\
\mathrm{kg}\end{array}$} & $4-8 \mathrm{~mm}$ & & 86.4 \\
\hline & $8-12 \mathrm{~mm}$ & & 80.6 \\
\hline \multirow{2}{*}{$\begin{array}{l}\text { C.A } \\
\mathrm{kg}\end{array}$} & $0-5 \mathrm{~mm}$ & & 250 \\
\hline & $4-8 \mathrm{~mm}$ & & 250 \\
\hline \multicolumn{2}{|c|}{ S.F. $\quad \mathrm{kg}$} & & 34.3 \\
\hline \multicolumn{2}{|c|}{ W lit } & & 97.7 \\
\hline \multicolumn{2}{|c|}{ HRWR $\quad$ lit } & & 7 \\
\hline \multicolumn{2}{|l|}{ Slump } & $\mathrm{mm}$ & 60 \\
\hline \multicolumn{2}{|c|}{ Concrete compressive strength @ 28 days } & $\mathrm{N} / \mathrm{mm} 2$ & 35 \\
\hline \multicolumn{2}{|l|}{ Density } & $\mathrm{kg} / \mathrm{m} 3$ & 2000 \\
\hline
\end{tabular}




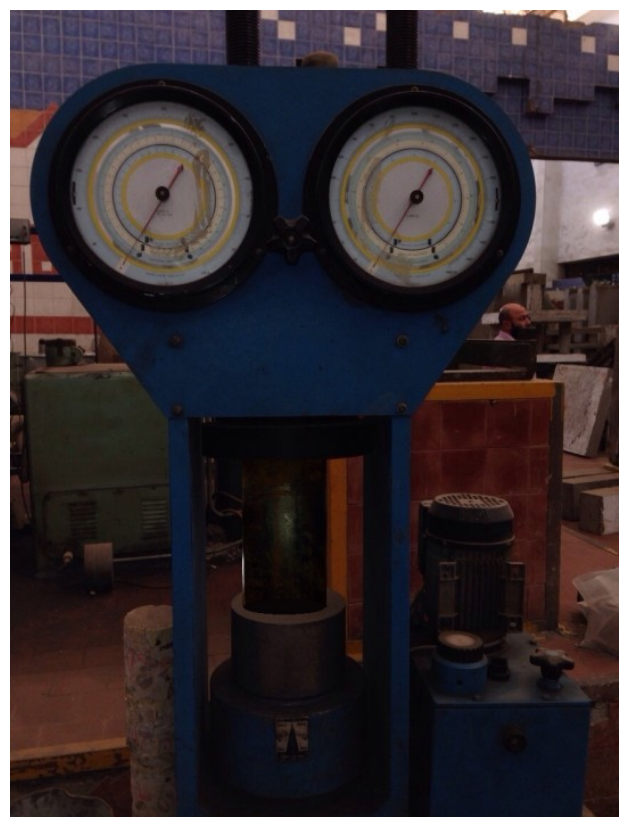

Figure 1:Compressiontestsetupoftheconfinedconcretecylinders.

\section{CASe StUdies ( AURORa ARCH BRIDGe)}

The Aurora arch bridge [19] consists of 8-inch steel pipes filled with concrete for both upper and lower chord. The lower chord is post-tensioned to 90 kips. FRP honeycomb panels are used for bridge deck. (Fig. 2) shows the arrangements and dimensions of the bridge
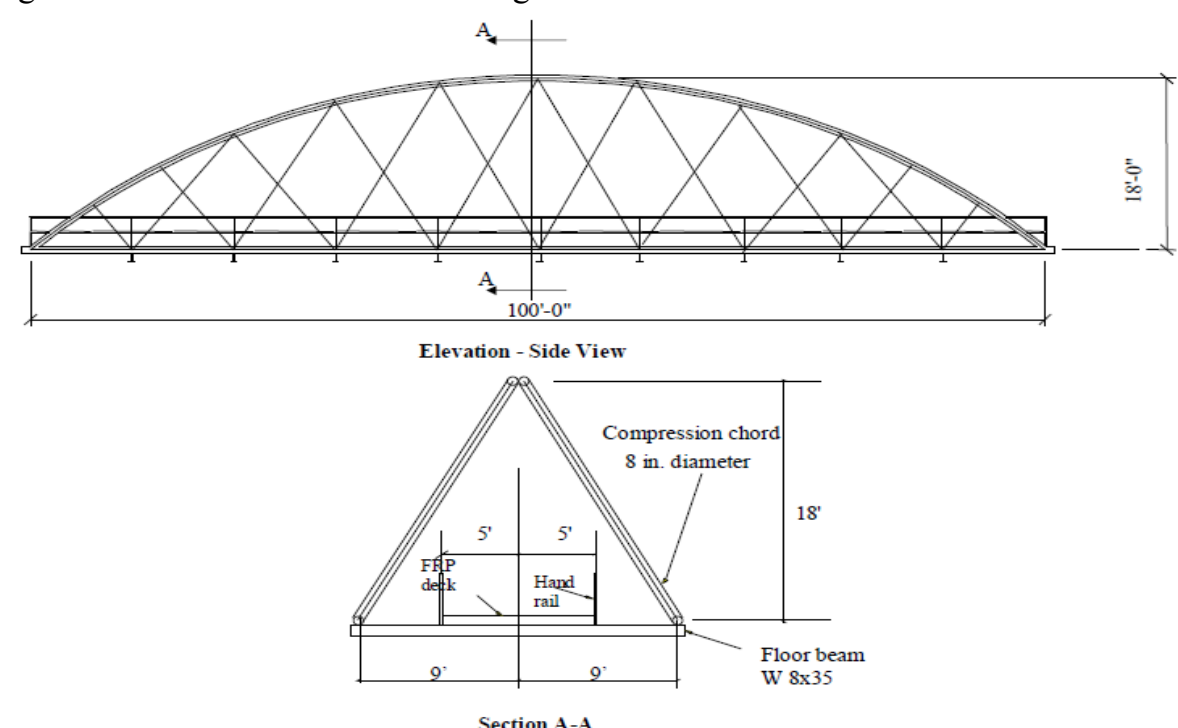

Figure 2: Configuration of the arch bridge

The bridges is analyzed using the developed computer program (Ismail, [20]) using three element types:- 1) Elements using the hollow steel tube (HST), 2) Elements casting using the normal strength concrete filled steel tube (NCFST), 3) Elements casting lightweight high strength concrete filled steel tube (LWHCFST) with the same compressive strength. The dead load is first applied to the bridge, and then a uniformly distributed load is applied to the deck in increments until maximum capacity of the bridge is reached. The ultimate strength of the bridge is achieved when an equivalent failure mechanism occurs. The deflected shapes of the bridge under the dead load effect, at the formation of the first plastic hinge (when the maximum capacity of any element in the bridge is reached) and under the ultimate load effect when the real failure mechanism is occurred are plotted.

\section{ULTIMATE LOAD ANALYSIS}

Figure (3) shows the deflected shape of the hollow steel tube (HST) bridge under the effect of different load levels. The first plastic hinge is when the applied load reaches a 10.8 times the dead load. A kink of a hinge in the deck profile at mid nodes is clear, indicating occurrence of an equivalent failure mechanism, when the 
applied load reaches 12.30 times the dead load. Figure (4) shows the deflected shape of the (NCFST) bridge under the effect of different load levels. The first plastic hinge is also formed when 6.7 times the dead load is applied. An equivalent failure mechanism occurs when the bridge deck is subjected to a uniform load equals 7.10 times the dead load. Figure (5) shows the bridge deck deflection versus different load levels of (LWHCFST). The first plastic hinge is formed when 8.20 times the dead load is applied. The failure mechanism occurs when the bridge deck is subjected to a uniform load equals 11.10 times the dead load. Figure (6) shows deflection at mid span for different average applied load for the three types (hollow steel tube (HST), normal strength concrete filled steel tube (NCFST) as well as lightweight high strength concrete filled steel tube (LWHCFST)). It is noted that under the same level of applied average load, the deflection of midpoint of the bridge increase for hollow steel tube (HST) than other two types. Also, the average applied loads caused a failure mechanism of the lightweight high strength concrete filled steel tube (LWHCFST), is about twice that of hollow steel tube (HST) and about 13\% more than that of normal strength concrete filled steel tube (NCFST).

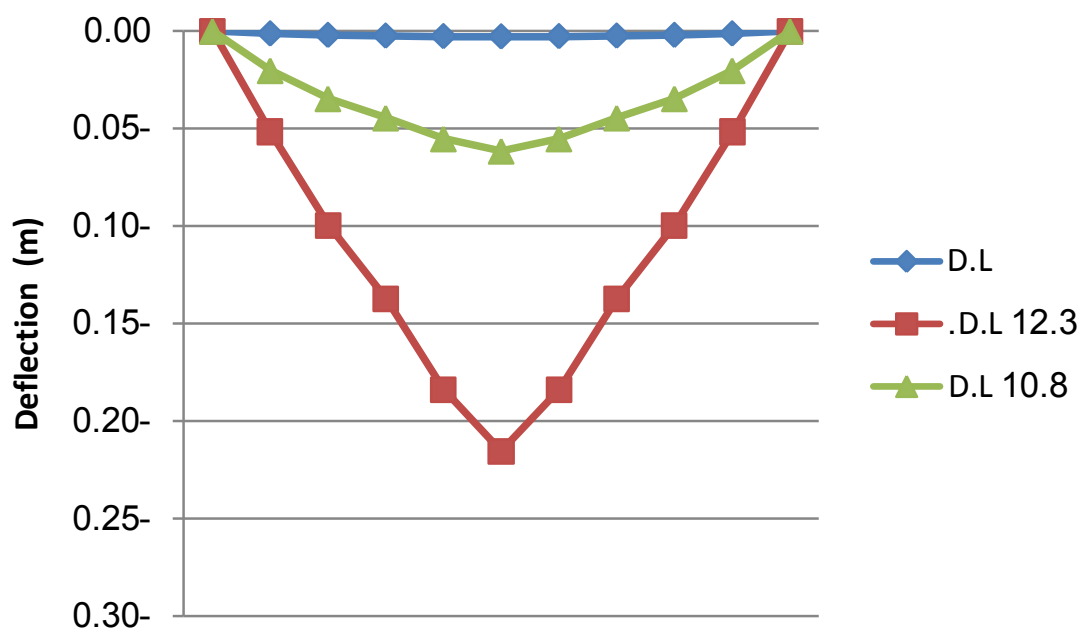

Figure 3: Deflected Shape of Bridge under the Effect of Different Load levels

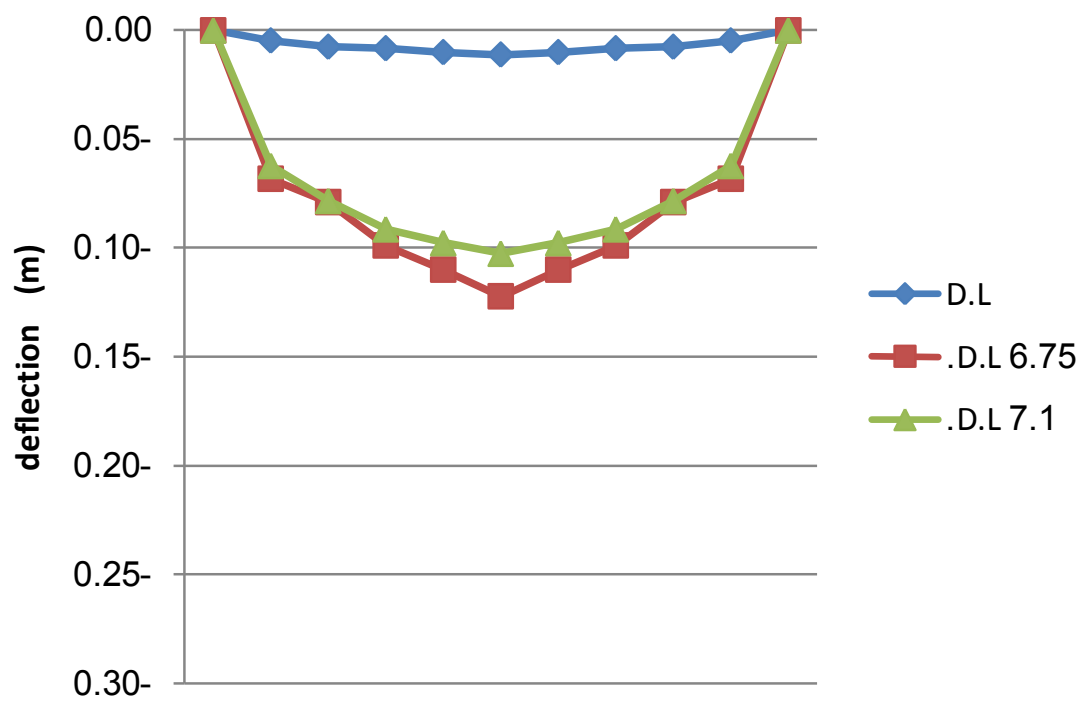

Figure 4: Deflected Shape of Bridge under the Effect of Different Load levels 


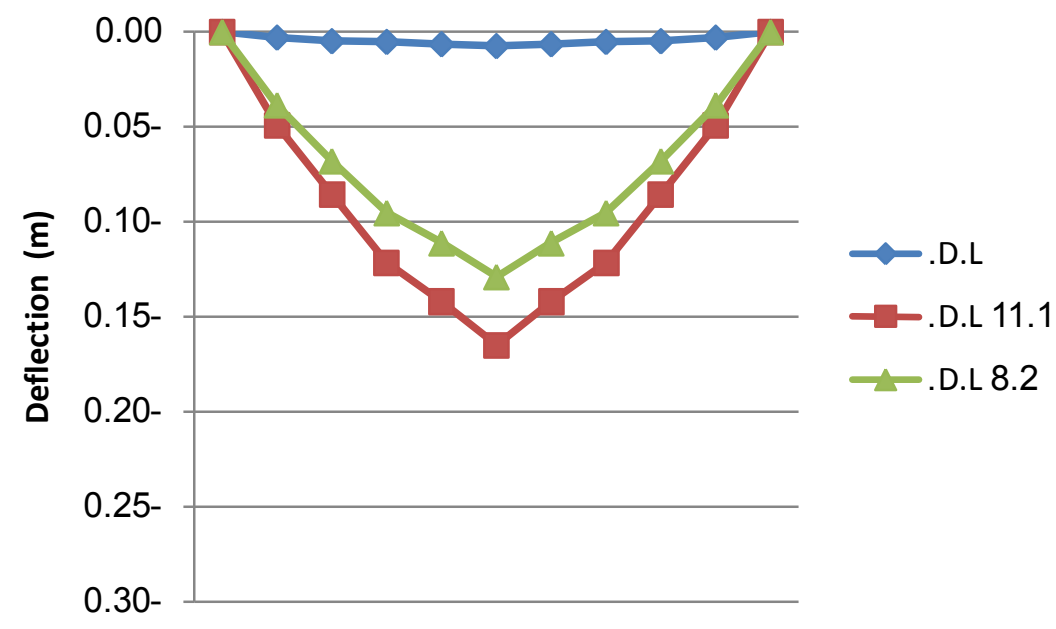

Figure 5: Deflected Shape of Bridge under the Effect of Different Load levels (LWHCFST)

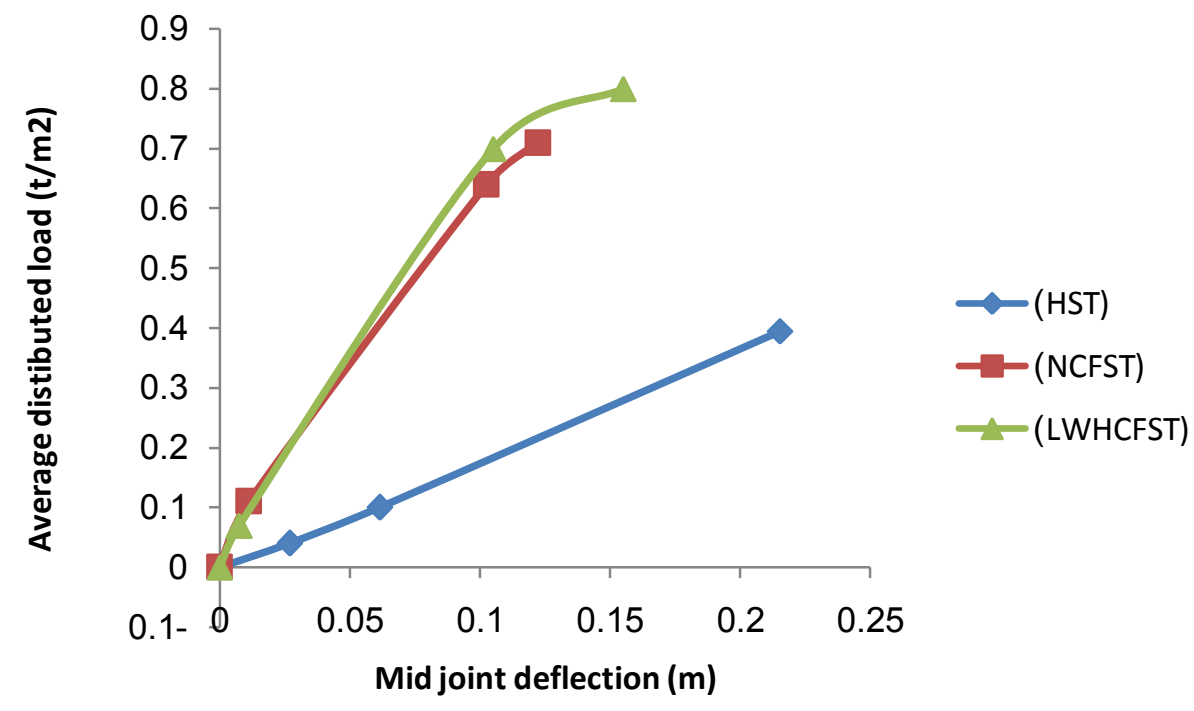

Figure 6: Mid Span Deflection for Different applied average Load for the Three bridge Types

\section{SUMMARY AND CONCLUSIONS}

A developed nonlinear finite element computer program was used to investigate the static nonlinear behaviour of (LWHCFST) up to failure. Three case studies; normalweight, lightweight high strength concrete and hollow steel tube (HST) were investigated under the effect of an incremental uniformly distributed load until the ultimate strength of the bridge is achieved when an equivalent failure mechanism occurs. Comparison of results shows that for bridge systems with the same bridge geometry and cross sectional and same compressive strength of concrete of deck, for the particular data used in this study, the (LWHCFST) resists a failure load $13 \%$ higher than that of the (NCFST) with the same compressive strength. Also, the percentages of failure loads for (LWHCFST) respect to dead load is 64\% higher of that of (NCFST). These results give the advantages of using high strength lightweight concrete to reduce the total weight of the bridge without reducing the total ultimate loads of the bridge, which gives the ability to increase the used live loads or have longer spans.

Strength of concrete members can be significantly improved with the provision of transverse confinement. The benefits from concrete confinement can be utilized in many applications in reducing structure weights, longer spans, etc. 


\section{REFERENCES}

[1] Roeder C.W., Cameron, B. and Brown, C.B. "Composite action in concrete filled tubes. Journal of Structural Engineering, ASCE, 125(5), pp. 477-484, 1999.

[2] Varma, A.H., Ricles, J.M., Sause, R. and Lu, L.W." Experimental behavior of high strength square concrete-filled steel tube beam-columns", Journal of Structural Engineering, ASCE, 128(3), pp. 309-318, 2002.

[3] Zhen, Z., Chen, B. and Wu, Q. "Recent development of CFST arch bridge in China", Proceeding of 6th ASCCS Conference, U.S.A., pp. 205-212. 2000.

[4] Clawson, W.C. "Bridge applications of composite construction in the U.S.", Structural Engineering in the 21st Century, Proceedings of the 1999 Structures Congress, pp. 544-547. 1999.

[5] Nakamura, S. "New structural forms for steel/concrete composite bridges". Structural Engineering International, Journal of the International Association for Bridge and Structural Engineering (IABSE), pp. 45-50, 2000.

[6] Liu, Y., Hikosaka, H. and Chen, B.: Static characteristics and nonlinear seismic response of concrete-filled tubular arch bridge with half-though deck, Steel Construction Engineering, 23(6), pp. 53-61. 1999.

[7] Liu, Y., Hikosaka, H. and Chen, B.: Structural characteristic and seismic performance of steel-concrete composite tied arch bridge rigidly connected to piers, Journal of Structural Engineering, JSCE, 47A, pp. 1475-1484, 2001.

[8] Liu, Y. and Hikosaka, H. "Assessment for ultimate strength and seismic performance of braced-rib arch bridge using concretefilled tubes", Journal of Structure Mechanics and Earthquake Engineering, JSCE, 703(I-59), pp. 313-325, 2002.

[9] Wu, Q., Takahashi, K., Matsuzaka, H., Chen, B. and Nakamura, S.? Study on dynamic properties of partially concrete filled steel tubular arch bridge, Journal of Constructional Steel, 10, pp. 141-148, 2002.

[10] Mander, J. B.; Priestley, M. J. N.; and Park, R., "Theoretical Stress-Strain Model for Confined Concrete," Journal of Structural Engineering, V. 114, No. 8, Aug. 1988, pp. 1804-1826.

[11] Mander, J. B.; Priestley, M. J. N.; and Park, R., "Observed Stress-Strain Behavior of Confined Concrete," Journal of Structural Engineering, V. 114, No. 8, Aug. 1988, pp. 1827-1849.

[12] Watson, S.; Zahn, F. A.; and Park, R., "Confining Reinforcement for Concrete Columns," Journal of Structural Engineering, V. 120, No. 6, June 1994, pp. 1798-1825.

[13] Yehia, S. A., and Tuan, C., "Aurora Arch Bridge - Testing and Evaluation of the Bridge Components," Technical Report, University of Nebraska, 2001.

[14] ACI Committee 213, "Guide for Structural Lightweight Aggregate Concrete," ACI Manual of Concrete Practice, American Concrete Institute, 2003.

[15] Meyer, Karl F., and Kahn, Lawrence F., "Lightweight Concrete Reduces Weight and Increases Span Length of Pretensioned Concrete Bridge Girders," PCI JOURNAL V. 47, No. 1, January-February 2002, pp. 68-75.

[16] Lo Yt Tommy and Cui Hz (2004), Effect Of Porous Lightweight Aggregate On Strength Of Concrete, Materials Letters, 58: 916919.

[17] KhalooR., Sharifian M. "Behavior Of Low To High-Strength Lightweight Concrete Under Torsion. Ijce. $2005 ; 3$ (3 And 4), 182 -191.

[18] O. Arioz, K.Kilinc, B. Karasu, G. Kaya, G. Arslan, M. Tuncan, A. Tuncan, M. Korkut And S. Kivrak " A Preliminary Research On The Properties of Lightweight Expanded Clay Aggregate" Journal of Aust. Ceram. Soc. 44 [1] (2008) 23-30.

[19] Sherif A. Yehia, Christopher Tuan, Ayman M. Ismail, Ashraf EissaMorshed "Construction of 100-Foot Long Pedestrian Arch Bridge Using Confined Concrete" International Conference on Bridge Management Systems_Monitoring, Assessment and Rehabilitation, March 2006, Cairo, Egypt.

[20] Ismail, A.M., "Nonlinear Analysis of Bridge Girders Under Static and Dynamic Loads", Ph.D. Dissertation, Ain Shams University, Cairo, Egypt, 2002. 